M.S. Demydov, D.0. Astafiev, P. Kaminski

\title{
SPECIALTIES OF COAL SEAMS MINING UNDER CONDITIONS OF WESTERN DONBAS
}

Problems that limited usage of plow systems in conditions of Western Donbas are considered. Analysis of plow systems work in Ukraine and abroad is given. Prospects for further research and sharp problems solution in coal industry of Ukraine are established.

\section{ОСОБЛИВОСТІ ВІДПРАЦЮВАННЯ ВУГІЛЬНИХ ПЛАСТІВ СТРУГОВИМИ КОМПЛЕКСАМИ В УМОВАХ ЗАХІДНОГО ДОНБАСУ}

Розглянуто проблеми, які обмежують застосування стругової техніки в умовах західного Донбасу. Наведено аналіз роботи стругів в Україні та за кордоном. Встановлено перспективи подальших досліджень та вирішення гострих проблем вугільної галузі україни.

\section{ОСОБЕННОСТИ ОТРАБОТКИ УГОЛЬНЫХ ПЛАСТОВ СТРУГОВЫМИ КОМПЛЕКСАМИ В УСЛОВИЯХ ЗАПАДНОГО ДОНБАССА}

Рассмотрены проблемы, ограничивающие применение струговой техники в условиях Западного Донбасса. Приведен анализ работы стругов в Украине и за рубежом. Установлены перспективы дальнейших исследований и решений острых проблем угольной отрасли Украины.

ISSUE AND ITS CONNECTION WITH SCIENTIFIC AND PRACTICAL TASKS

Nowadays, one of the main tasks of Ukrainian coal industry is increasing labour productivity by means of complex mechanization and automatization of mining operations with usage of modern equipment. The best example is implementation of modern plow complexes on Western Donbas mines, PJSC "DTEK Pavlogradvugillia".

Currently, plowing is one of perspective directions of coal extraction development. Alternatively, to shortwall stoping machines with help of plow complexes we have opportunity to reach high-grade quality of extracted coal and decrease ash content by means of wall rock cutting reduction. As a result, we can increase quality of finished products in several times.

The main issue that retards widespread use of plow techniques in Western Donbas is hard mine-geological conditions (low thickness of coal seams, low rocks hardness of main and immediate roof, high inflow of water in mine workings, etc.).

\section{RESEARCH ANALYSIS OF GIVEN ISSUE}

Experience of plow techniques usage on coal mines has been considered on many data sources.

Implementation of plow techniques on LW Bogdanka mine is considered in article [1]. Author Zbigniew Stopa describes mine-geological conditions of operations conducting and industrial results that were received in stoping face 
1/VI on seam 385/2. In work [2] author substantiates advantages and disadvantages of plow complexes application during mining of thin and very thin seams comparatively with traditional methods of shearer mining. Also in this work described experience and practical results of plowing in stoping faces of JSW S.A. mine, where a large part of stocks composes in thin coal seams.

Operation of plow complex in hard minegeological conditions is considered in work [3]. The author proposed different technological schemes of coal seam mining in hard conditions on the base of wide experience of plow techniques implementation.

In work [4] covered the question about plow complex application in conditions of Western Donbas. A model of coal-bearing massif and mechanized complex was built on the base of computer and experimental research.

In spite of the fact that considerable volume of research in given area had been realized, the question about implementation of plow complexes in Ukraine is still very actually. Equipment adaptation under local minegeological conditions is necessary for successful application of plow techniques. Rational parameters substantiation of operations that will allow leading accident-free mining of extraction mine working is also necessary.

\section{PURPOSE AND OBJECTIVES}

The main purpose of this article is analysis of global and native experience of plowing application in coal industry and perspectives of plow complexes widespread use in hard minegeological conditions of Western Donbas.

To achieve given purpose authors established following objectives:

1. To analyze experience in plow systems application in Ukraine and abroad;

2. To consider factors that retard largescale implementation of plow systems on Western Donbas mines.
STATEMENT OF MAIN MATERAL AND SUBSTANTIATION OF OBTAINED RESEARCH RESULTS

Plow systems are widely operated on seams with low and medium thickness in leading coal mining countries. Modern plow complexes have high reliability and capacity that provides good productivity during coal extraction and absence of workers in working area with help of automatization systems.

On German coal mines development of seams with thickness from 0.6 to $2 \mathrm{~m}$ is conducted with help of modern plow systems. Spectacular example can be stoping face operation on "Prosper Haniel" mine, where average daily production was equal to more than 10,000 tons in August 2003 [5].

Experience in plow techniques application on German mines shown supportability of high rates on thin (to $1 \mathrm{~m}$ ) seams. Example is "Niderberg" mine, where in 1998 on seam with thickness $0,75 \mathrm{~m}$ average load on longwall with length $318 \mathrm{~m}$ was equal to 3339 tons per day, on mine "Friedrich Heinrich" 3270 tons per day at longwall length $280 \mathrm{~m}$ and seam thickness $0,86 \mathrm{~m}$. In 2006 on eight German mines were 21 stoping faces in exploitation, average load on longwall was equal to 4000 tons of marketable coal, near 50 million tons of run-of-mine coal.

As for operating expenses during coal extraction and prime cost of coal, maintenance of shearer faces in Germany is almost on $9 \%$ more expensive than plowing. Comparison of the most productive longwalls show weightier results: extraction in plow stope is almost on $20 \%$ cheaper than in shearer one.

Especially good results of plow techniques application were achieved on "Bogdanka" mine (Poland). During extraction of seam with thickness $1,63 \mathrm{~m}$ managed to reach productivity in 17000 tons per day.

On Russian mines, quantity of extracted coal with help of plow systems grows up. For example, on "Abashevska" mine, coal seam with thickness $1,36-1,58 \mathrm{~m}$ and longwall length $220 \mathrm{~m}$ was developed face with help of "DBT GMbH" with plow "GH 9-38ve/5.7". 
Average daily production was equal to 4500 tons.

On Figure 1 shown comparison diagram of stoping faces productivity that equipped by plow systems.

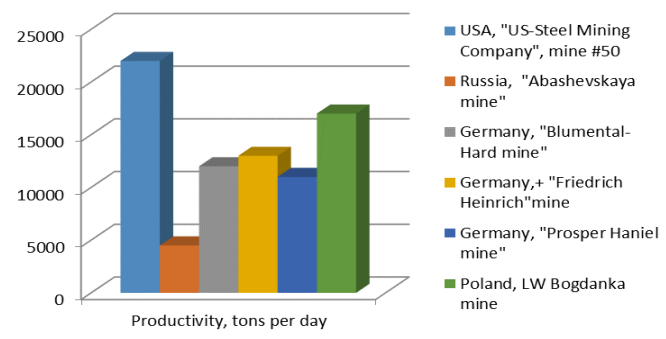

Fig. 1. Productivity of leading coal mines that equipped by plow systems

At present time in Ukrainian coal industry quantity of stoping faces with plow systems gradually increases, however most of longwalls are still equipped by shearers (Table).

From 165 working faces 91 was equipped with supports of new technical level, 59 - oldfashioned and in 6 stoping faces used supports of foreign manufacture, including 3 complexes of Czech firm Ostroj and 2 of German DBT.

Most part of stoping faces (97 units) worked on thin coal seams (less than 1,2 m) in Ukraine and spectacular example is mining of longwall $161^{\text {st }}$ seam $C_{6}$ "Stepova" mine "Pershotravneve" Mine Management PJSC "DTEK Pavlogradvugillia" [6]. Production unit is situated on the depth $300 \mathrm{~m}$ and developing updip on seam $C_{6}$ (average angle of $\operatorname{dip} 4^{\circ}$ ) with extracting seam thickness $0,9 \mathrm{~m}$. In longwall with length $300 \mathrm{~m}$ reached average load on stoping face 3000 tons, but in some period, it ranges to 5000 tons per day.

AVERAGE DAILY LOAD ON LONGWALL IN MINES THAT EQUIPPED WITH COAL-CUTTING

Table SHEARERS AND PLOWS WITH PRODUCTIVITY MORE THAN 2000 TONS PER DAY

\begin{tabular}{|l|c|c|c|c|c|}
\hline \multicolumn{7}{|c|}{ Mine } & $\begin{array}{c}\text { Complex } \\
\text { type }\end{array}$ & Plow type & $\begin{array}{c}\text { Longwall } \\
\text { length, } \mathrm{m}\end{array}$ & $\begin{array}{c}\text { Seam thick- } \\
\text { ness, } \mathrm{m}\end{array}$ & $\begin{array}{c}\text { Load on long- } \\
\text { wall, tons per day }\end{array}$ \\
\hline \multicolumn{7}{|c|}{ Shearer faces } \\
\hline $\begin{array}{l}\text { Mine Management } \\
\text { "Pokrovske" }\end{array}$ & $\begin{array}{c}\text { MKY } \\
0423\end{array}$ & JOY-LS 20 & 320 & $1,74-1,94$ & 4056 \\
\hline $\begin{array}{l}\text { "Pavlogradska" mine } \\
\text { PJSC "DTEK Pavlo- } \\
\text { gradvugillia" }\end{array}$ & Ostroj & MB444P & 269 & $0,98-1,05$ & 2296 \\
\hline Mine "n.a. O. Zasiadko" & 3 KD90 & 1 GSH-68 & 280 & $1,41-1,73$ & 2168 \\
\hline \multicolumn{7}{|c|}{ Plow faces } & $0,8 / 1,4$ & 3000 \\
\hline $\begin{array}{l}\text { Mine Management } \\
\text { "Pokrovske" }\end{array}$ & $\begin{array}{c}\text { Bucyrus } \\
\text { DBT }\end{array}$ & RHH42 & 290 & $0,9 / 1,2$ & 3200 \\
\hline $\begin{array}{l}\text { "Stepova", Mine PJSC } \\
\text { "DTEK Pavlograd- } \\
\text { vugillia" }\end{array}$ & $\begin{array}{c}\text { Bucyrus } \\
\text { DBT }\end{array}$ & $\begin{array}{c}\text { GH } \\
9.38 \mathrm{ve} / 5.7\end{array}$ & 300 & \\
\hline
\end{tabular}

In spite of definitely rhythmical work of face complex, daily average rate of stoping face changes in sufficiently wide range, in particular due-to emergency shut downs during of which was observed intensification of rock pressure manifestations by way of roof lowering, increasing of load on support and wearing-out of pressure-release valves on hydraulic props of some support sections. Also, observe perturbations of rock pressure manifestations intensity at different daily average advance rates of stoping face. For instance, during two months of this year happened seven emergency shut downs of plow complex with duration of more than 12 hours. The reasons were different, including roof rocks inrush. These shut downs concur in space with sharp decreasing of immediate roof two 
layers thicknesses to $0,4-0,6 \mathrm{~m}$ that represented by siltstones and mudstones with thinfoliated structure and poor binding with adjoining lithological differences. Also poor binding observes between layers of main roof that also represented by siltstones and mudstones with total thickness $11-12,5 \mathrm{~m}$, but upper boundary of collapsible main roof is seam $C_{6}^{1}$, where binding with underlying laying is completely absent. Computer monitoring is realized by means of periodical data sampling from operations system management in longwall.

However, seams mining on "Stepova" mine has own specific character that connected with hard mine-geological conditions:

- rocks of roof and bottom are weaker than seams $(f=1-4)$, slightly metamorphosed, foliated and fractured;

- high strength characteristics of coal seams $(f=3-4$ prof. Protodiakonov scale);

- certain lithological varieties (sandstones, small coal seams and interlayers with high water inflow that lead to siltstones and mudstones and decrease their durability;
- low cohesion between main and immediate roof layers.

These specialties essentially decrease conditions of mining operations conduction because of rock pressure manifestations intensity, but thin and very thin coal seams do not support to high-productive mining.

\section{CONCLUSIONS AND PROSPECTS OF FURTHER RESEARCH}

1. Plow techniques are very perspective for implementation on Ukrainian coal enterprises.

2. We can change shearers on seams with thickness to $1,6 \mathrm{~m}$ and get a high production, coal of the highest grade of quality and lower ash content by means of full reject from wall rocks cutting with help of plow systems.

3 . It is necessary to take into account specifics of hard mine-geological conditions for providing accident-free operation of extraction units. For Ukrainian coal industry and especially Western Donbas during plow complexes usage.

\section{REFERENCES}

1. Stopa Z. Plow techniques in LW Bogdanka S.A. - currently situation and development / Z. Stopa // International Mining Forum. - 2011. - $42 p$.

2. Tor A. Current experience and further drafts in plow techniques application in JSW S.A. / A. Tor // International Mining Forum, 2011. - $43 p$.

3. Voss H-W. Plow complexes operations in stoping faces with hard geological conditions / H-W. Voss // International Mining Forum, 2011. $-44 p$.

4. Геомеханіка навантаження кріплення очисних та підготовчих виробок в шаруватому масиві слабких порід: монографія / [Бондаренко В.І., Ковалевська І.А., Симанович Г.А., Черватюк В.Г.]. - Д.: ЛізуновПрес. 2012. $-236 c$.
5. Voss H-W. Mechanical equipment for coal development that used in Germany for mining of seams with low and medium thickness / Heinz-Werner Voss \& Manfred Bittner // Gluckauf. - 2003. - \#3. - P. $14-19$.

6. Звягильский Е.Л. О необходимости широкой модернизации угольной промышленности Украины /Е.Л. Звягильский, Ю.С. Залознова // Научный доклад. Донещк, 2013.

\section{ABOUT AUTHORS}

Maksym Demydov - assistant of Underground Mining Department at National Mining University.

Denys Astafiev - Ph.D student of Underground Mining Department at National Mining University.

Pawel Kaminski - research assistant at AGH University of Science and Technology (Krakow, Poland). 